\title{
To green or not to green: Establishing the economic value of green infrastructure investments in The Wicker, Sheffield.
}

\author{
Ian C. Mell ${ }^{1}$, John Henneberry ${ }^{2}$, Sigrid Hehl-Lange ${ }^{3}$ and Berna Keskin ${ }^{2}$
}

1. Department of Geography \& Planning School of Environmental Sciences, University of Liverpool, Gordon Stephenson Building, 74 Bedford Street South, Liverpool L69 7ZQ, UK (I.C.Mell@liverpool.ac.uk).

2. Department of Urban Studies \& Planning, University of Sheffield, Western Bank, Sheffield S102TN, UK (j.henneberry@sheffield.ac.uk; b.keskin@sheffield.ac.uk).

3. Department of Landscape University of Sheffield, The Arts Tower, Western Bank, Sheffield S10 2TN, UK (s.hehl-lange@sheffield.ac.uk)

\begin{abstract}
Establishing the value of urban green infrastructure resources draws on a complex evaluation of social, economic and ecological influences. As a result planners have found it difficult to develop robust economic arguments to promote investments in urban greening. The Valuing Attractive Landscapes in the Urban Economy (VALUE) project facilitated a trans-national programme of investigations to establish economic values for a range of green infrastructure investments. This paper presents the results of a large-scale willingness to pay (WTP) survey (N: 510) for investments on Blonk Street, The Wicker, Sheffield. Using 3D visualisations of three alternative urban greening scenarios the research addressed the influence of green infrastructure on aesthetic quality, functionality and amenity. The evidence suggests that participants were WTP up $£ 10.56$ or $2 \%$ more in monthly rent or additional mortgage payments to live in locations that have a high quality green infrastructure environment. The survey also examined the relationships between a range of socio-economic factors and WTP for green infrastructure (GI). WTP more rent was associated particularly with those in younger age groups and those with lower educational attainment. The paper concludes that investment in urban GI that is visibly greener, that facilitates access to GI and other amenities and that is perceived to promote multiple functions and benefits on a single
\end{abstract}


site (i.e. multi-functionality) generate higher WTP values. The findings of the study support the wider literature evaluating the economic value of GI which argues that investment in urban greenspace can have a significant impact on local housing and commercial markets where it produces more attractive and functional landscapes.

Key words: urban greening, urban planning, 3D visualisations, economic evaluation, green infrastructure

\section{Status}

Authors' final version, published in Urban Forestry \& Urban Greening at:

http://dx.doi.org/10.1016/j.ufug.2016.06.015

DOI: 10.1016/j.ufug.2016.06.015 


\section{Introduction}

The River Don in The Wicker (Sheffield, UK) experienced severe flooding following the single highest one-day rainfall event since 1882 in June 2007. The impacts extended to tens of millions of pounds of construction and commercial damage, disruption to the road and rail networks and the loss of two lives ${ }^{1}$. One cause was the engineered channelization and removal of stabilising vegetation from the river channel. However, a confluence of issues have been identified which collectively impacted the scale of the flood including changes in the management of the physical form of the river channel to speed up the dissipation of rainfall downstream, increased stormwater run-off into the channel from impermeable street surfaces $^{2}$, and the perceptions of local people to the capacity of the River Don to deal with flood events (Environment Agency, 2007). The negative coverage of the flooding influenced the decision of Sheffield City Council (SCC), and associated agencies, to modify their development strategies for the area. This included evaluating the appropriateness of the existing river management regime and remodelling the urban realm to promote investment in The Wicker (Mell et al., 2012a).

Despite the visible ecological damage caused by the 2007 floods, reflections on its impact focussed most frequently on the economic costs of the event. Discussions highlighted the effects on the physical and built environment of The Wicker, and on the economic development of Sheffield as a whole. It also brought to the fore the perception that environments susceptible to flooding are less desirable places to live (South Yorkshire Forest Partnership \& Sheffield City Council, 2012). To address the redevelopment needs of The Wicker (Fig. 1), SCC's vision was to create a socially and environmentally sustainable commercial-residential neighbourhood in the area. To achieve such a transformation SCC proposed investing in a combination of built and green infrastructure to ensure that The Wicker is able to (a) withstand any potential damage of further flood events, (b) be promoted as a vibrant community hub and (c) act as an economically functional and attractive entrance to Sheffield city centre. One project evaluating the relationship between the development of ecological and social functionality in conjunction with an economically viable urban realm

\footnotetext{
${ }^{1}$ Approximately 1200 homes and 1000 businesses were affected by the flooding. Chatterton et al. (2010) estimated that the cost of disruption to local businesses was over $f 50$ million.

${ }^{2} 70 \%$ of the water in the channel came via stormwater run-off from impermeable surfaces (Environment Agency, 2007).
} 
was the multi-institution INTERREG IVB project 'Valuing Attractive Landscapes in the Urban Economy' (VALUE).

This paper presents an analysis of a large-scale survey of preferences for green infrastructure $\left(\mathrm{GI}^{3}\right)$ undertaken to establish the social and economic values of such investment. We focus on establishing respondents' willingness to pay (WTP) for a set of contrasting development scenarios that were presented through 3D visualisations of the River Don/Blonk Street (Fig.

2-4). Through this evaluation the paper examines the scale of the economic returns associated with specific green investment options that might potentially be generated for local authorities (LAs), developers and land/home owners. The socio-ecological influences underpinning such returns are also explored. The paper's central findings indicate that people base their WTP on an integrated assessment of social, ecological and economic benefits of GI and that the greener and more functional an investment appears to be in terms of access and availability of amenities and services, the greater is their WTP for it.

\section{Valuing urban green space}

The value of urban environments varies depending on the complex interaction of social, economic and ecological factors. However, extensive research (cf. Beatley, 2000) indicates that locations considered aesthetically pleasing and functional are perceived to hold higher social and economic benefits, as they facilitate affordances, promote liveability and are more attractive places to live (Thwaites et al., 2007; Louv, 2005). Conversely, publicly accessible landscapes that are associated with negative social activities, such as vandalism, are often considered exclusionary and unattractive (Natural England \& Landuse Consultants, 2009). One problem faced by planners has been to achieve a balance between establishing socially inclusive places whilst also promoting economic viability.

Despite the breadth of policy, coupled with research highlighting the value of places that promote a range of socio-economic functions, there has been a reticence by practitioners to establish economic values for green infrastructure because of the complexity of rationalising competing variables associated with urban landscapes (Benedict \& McMahon, 2006).

\footnotetext{
${ }^{3}$ Green Infrastructure (GI) is considered within this paper as the natural elements of the built environment that support a variety of social, economic and ecologically functions at a local, city and regional scale. GI is proposed as a network of green and water-based resources that promote connectivity between people and places, as well as, providing climatic and ecosystem service functions (Mell, 2010). Within the paper $\mathrm{Gl}$ is used interchangeably with green space and urban greening; each reference is based on an understanding of the rationale for GI outlined above.
} 
Partially this reflects a potential lack of expertise of 'urban planners' and 'landscape professionals' in economic valuation techniques and illustrates the inherent difficulties placed on policy makers and practitioners if, and when, they are required to financially quantify the cost-benefits of investment in green infrastructure (Garrod et al., 1993; Willis \& Garrod, 1992). It has been argued that one of the underlying reasons for this is the difficulty of incorporating both the tangible and intangible benefits associated with environmental resources into robust estimates of economic values (Mell, 2013). Compared to investments in grey infrastructure it has been suggested that estimating the value of urban GI is subject to a more diverse range of economic caveats, despite its capacity to create smarter, more sustainable and inclusive environments (Lachmund, 2013; Campbell, 1996).

Conceptually the process of valuation could be considered to undermine the intrinsic value of landscape resources. Research exploring the innate value of nature is well grounded (cf. Nassauer, 1995; Pepper, 1996), however, the rationale for investment frequently neglects assessments of the intangible characteristics attributed to environmental resources. Furthermore, Liu et al. (2010) and Daily et al. (2009) question whether it is appropriate to explore monetary valuations of nature, and if so whether the calculations can ever be meaningful. They argue that a realistic value of nature would be trillions of dollars, effectively rendering such calculations meaningless and un-actionable. The problem is that the value of nature, and therefore by extension urban greening, has more recently become subsumed within economic growth narratives, as urban environments become increasingly commodified (Mell et al., 2013).

The synergistic value of human-environmental relationships is, as a consequence, potentially diminished when planners attempt to promote economic rationales for development above environmental or social objectives (UNEP-WCMC, 2011; Selman, 2009). Moreover, despite Pepper (1996:52) stating that 'such value[s] cannot be defended rationally, only asserted', this suggests that any attempt to value nature may potentially be undermined by a lack of robust economic evidence compared to other built infrastructure valuations. Unfortunately, this has limited the dialogue between green space planners and developers who have failed, in many cases, to identify the variations between the economic and 'intrinsic' values of urban greening (Vandermeulen et al., 2011). However, there is a wealth of experience and expertise within the built environment profession, notably in architecture and surveying, which could 
be brought into these discussions. Unfortunately, there is reluctance in some cases to broaden the number of partners needed to deliver projects due to concerns over costs or overcomplicating the development process (Wilker \& Rusche, 2013; Jim, 2004). Assumptions that GI 'is something nice to have' once development is complete - an afterthought - therefore persist within urban planning (Walmsley, 2006). The lack of clarity over how economic values may be generated by urban greening also weakens the ability of environmental managers' to promote investment in green rather than grey infrastructure.

Attempts to integrate the presumptions of value proposed by Pepper (1996) within contemporary approaches to valuation in urban development have proved difficult. However, the development of GI planning has facilitated the advancement of such debates (Natural England and Landuse Consultants, 2009). Borrowing principles from alternative planning agendas (i.e. greenways, smart growth, sustainable urban development), GI planning has enabled LAs and developers to incorporates different valuation mechanisms within a more systematic approach to decision-making (Landscape Institute, 2009; Town \& Country Planning Association, 2004). A more deliberate process of economic valuation is thus being incorporated into discussions of development.

The UK National Ecosystem Assessment (UNEP-WCMC, 2011), was one such project, and was the first large scale evaluation of natural environment value undertaken in the UK. It estimated that the UK's landscape delivered a minimum of $£ 2$ billion per year to its economy through social and economic benefits, and ecosystem services. Natural England's (2013) longitudinal survey of green space use - Monitor of Engagement with the Natural Environment (MENE), produced similar findings concerning the value of GI to both the UK economy and the nation's well-being. Such large-scale assessments are rare compared with the local evaluations that are the most common form of enviro-economic investigation (Jim \& Chen, 2006; Tyrväinen \& Väänänen, 1998). Furthermore, although local assessments may enable evaluations of specific GI projects to be made, the applicability and transferability of results between locations is limited (Vandermeulen et al., 2011).

\section{Establishing value: visualisations and payments}

Investments in environmental improvements have been shown to increase the economic competitiveness of a location, as well as improving the quality of life there (Crompton, 2001; 
Willis \& Garrod, 1992). The value of the landscape may be affected by complex relations between the quality of place and socio-economic perceptions of a given location. Established government policy in the UK has identified, through a series of policy evaluations, that notwithstanding the innate values presented by Pepper (1996), measures of quality and value need to be reinforced with robust economic valuations. Economic data relating to GI may also be used to raise awareness of the commodity value of green infrastructure, increasing dialogue between policy-makers, investors and developers.

Commodification is a process whereby a resource, i.e. a street tree, is attributed an economic value based on the social, economic and ecological functions or services it can deliver to a given location. This process is though unequal as establishing an acceptable rationale for the commodification of a resource is fraught with disciplinary and fiscal uncertainties over what can, and is, economically valuable. Moreover, as commodity values are inherent variable because they are based upon both complementary and competing benefit provision establishing robust financial costs for landscape resources is difficult (Jones \& Somper, 2014). The commodification of environmental resources has therefore proved problematic for planners as balancing built environment values, which are relatively established, with the more intangible benefits of nature is not straightforward (UNEP-WCMC, 2011). However, to achieve such an integration of commodity values, government needs to work closely with advocacy agencies to promote a more integrated approach to socio-environmental and economic valuations. Prior to merging with the Design Council, CABE Space acted as an intermediary between these positions, promoting assessments of value that incorporate qualitative and quantitative aspects of place-making (CABE Space, 2004, 2005).

Pepper's argument that the innate valuation of nature is firmly grounded in societal norms is compelling, but has been critiqued within the academic literature because this view is not translated into action (Gómez-Baggethun et al., 2010; Pepper, 1996). Moreover, within consultation practices it could be argued that people are often unable to establish a realistic appreciation of how investments will alter/enhance the physical environment because 'development' is an abstract or intangible process. However, both historical and contemporary evidence suggests that more participatory master planning practices can aid personal and communal understanding of different investment options (Wilker et al., 2016; Lennon, 2014); the Wicker has itself been subject to a number of such practices. The process 
of valuation may therefore be undermined by personal and communal interpretations of landscape, which are manifested in superficial willingness to pay valuations (Bateman et al., 2002). To address the lack of coherence in landscape valuation there has been an increased use of visualisations to depict, in a realistic way, the form and scale of development proposals. Visualisations are also considered to assist respondents in their recognition of specific locations, which in turn enables them to synthesise the potential development options to facilitate more defined and robust valuations compared to the socio-cultural interpretations of WTP described by Pepper (Todorova et al., 2004).

While it would be unrealistic to disassociate personal perceptions from valuation studies, high quality visualisations have been reported to provide a bridge between abstract discussions of intangible benefits and a more realistic depiction of the opportunities under construction (Hehl-Lange et al., 2012). Visualisations therefore provide researchers with the tools to represent complex manipulations of a site to illustrate development opportunities to a variety of audiences. By visualising a range of development scenarios and presenting each in either $2 \mathrm{D}$ or $3 \mathrm{D}$, images (or videos) provide a mechanism to investigate a range of investment options within a structured and controlled environment (Lange, 2001). Visualisations also provide an additional level of control over the investigation, as they allow researchers to manage what is and is not shown to the respondent, thus limiting the variables under discussion. To ensure that respondents are afforded sufficient information regarding each visualisation it is also important to structure the survey vehicle appropriately to capture contributing qualitative and quantitative data to support subsequent analysis (Bateman et al., 2002; Willis \& Garrod, 1992). Such questions feature a reflective structure where participants can draw on their personal understandings of the landscape, whilst being guided through a series of increasingly refined questions about the investment (Mell et al., 2013).

When visualisations are used in conjunction with economic evaluation they highlight an additional level of complementarity between real-world assessments of an investment and realistic images of potential developments (Laing et al., 2002). This provides researchers with scope to focus more precisely on specific variables and to assess which variables have the most significant impact on WTP. The relationship between the use of 3D visualisations, perceptions and the potential influence on WTP was investigated as part of the VALUE project. 


\section{The VALUE Project}

VALUE brought together partners from Belgium, Germany, The Netherlands and the UK to investigate whether a trans-national approach to valuing GI could be developed. VALUE attempted to establish complimentary actions to enhance the economic and social performance of cities, towns and rural areas, promoting the economic potential of GI to increase the value of local and regional assets (Wilker \& Rusche, 2013; Mell et al., 2013; Vandermeulen et al., 2011). The project investigated whether consistency in approach and evaluation techniques could be established for a diverse suite of urban GI investments. Investigations were undertaken in ten locations enabling VALUE to generate a robust dataset illustrating whether GI investment options can generate comparable economic data between different urban environments (South Yorkshire Forest Partnership \& Sheffield City Council, 2012). The VALUE investment under investigation within this paper focuses on The Wicker, Sheffield (UK).

\section{The Wicker, Sheffield}

The Wicker has been subject to a series of development master plans. Its proximity to the centre of Sheffield and its strategic role as a gateway to the city has established it as a key development site (Fig. 1) (Sheffield City Council, 2009). However, due to its industrial heritage the area has been viewed as a transitional zone, which can be considered to be physically and psychologically isolated from the city centre (Mell et al., 2012a). It has also been historically associated with anti-social behaviour. The VALUE investment aimed to improve access to the area, raise the perceptions of its landscape quality through a series of urban greening initiatives and improvements to public transport. The VALUE investment strategy utilised the findings of the Urban River Corridor and Sustainable Living Agenda (URSULA) project (Wild et al., 2008), enabling the project to integrate additional evidence of the economic value of greening into the development process. The survey site, Blonk Street, is located in the south-east of The Wicker, is within the River Don corridor and is characterised by apartment and commercial development on either side of the channel. Prior to the VALUE investment the area had little visible or publically accessible GI. 
Figure 1. Map of Sheffield and The Wicker.

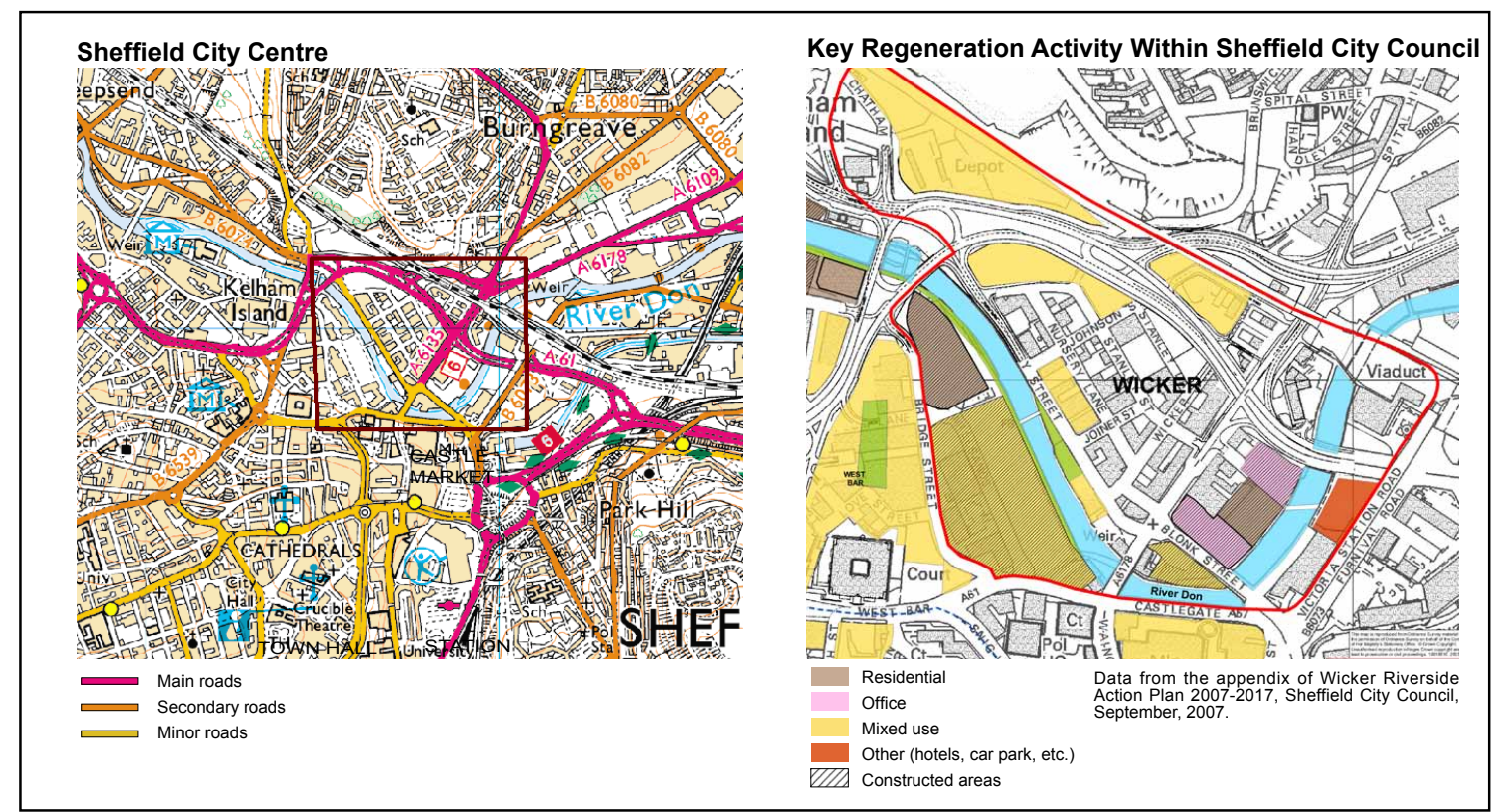

Source: URSULA (2011) Wicker Riverside: Options for Sustainable Redevelopment

\section{Methodology}

To estimate the economic value of urban greening in The Wicker a contingent valuation survey utilising 3D visualisations was developed. GI investments that were evaluated had, as their aims, improving access to the area, support for flood mitigation/control and the enhancement of urban green space (Fig. 2-4). The investments were physically framed by the River Don channel and incorporated SCC's proposed development scenarios of The Wicker (Mell et al., 2012a). The visualisations were used in conjunction with a willingness to pay (WTP) survey based on a hypothetical market for additional rental/mortgage payments. The survey was designed and administered in four sections:

1. An introduction to the survey and topic of urban greening;

2. Questions relating to the function of green spaces in Sheffield (Fig. 5);

3. Respondents WTP for investment options represented by 3D visualisations (Fig. 6); and

4. A reflection on the role of the Local Authority (LA) in creating, funding and maintaining green spaces in Sheffield. 
The survey was structured to enable respondents to think broadly about the role that GI plays in place-shaping before estimating the economic value of specific urban greening investments in The Wicker. The WTP elicitation question was complemented by contextual questions allowing the survey to establish a deeper understanding of preferences because '...cost is not "just money": it is an expression of resources that could be used for all kinds of other, perhaps equally deserving, purposes' (Bateman et al., 2002:19). The final set of questions provided scope for respondents to evaluate the responsibilities of the LA in place-making with regards to the delivery of amenities to meet social, economic and environmental needs. The structure and scope of the survey was defined by an extensive literature review of comparable WTP studies (Jim \& Chen, 2006; Tyrväinen, 2001; Tyrväinen \& Väänänen, 1998; Garrod et al., 1993; Willis \& Garrod, 1992), a previous VALUE investigation undertaken in Manchester (Mell et al., 2012b) and in line with the findings of a focus group event held prior to the commencement of the study (Anyika, 2011).

\section{Figure 2. Blonk Street: (Before)}

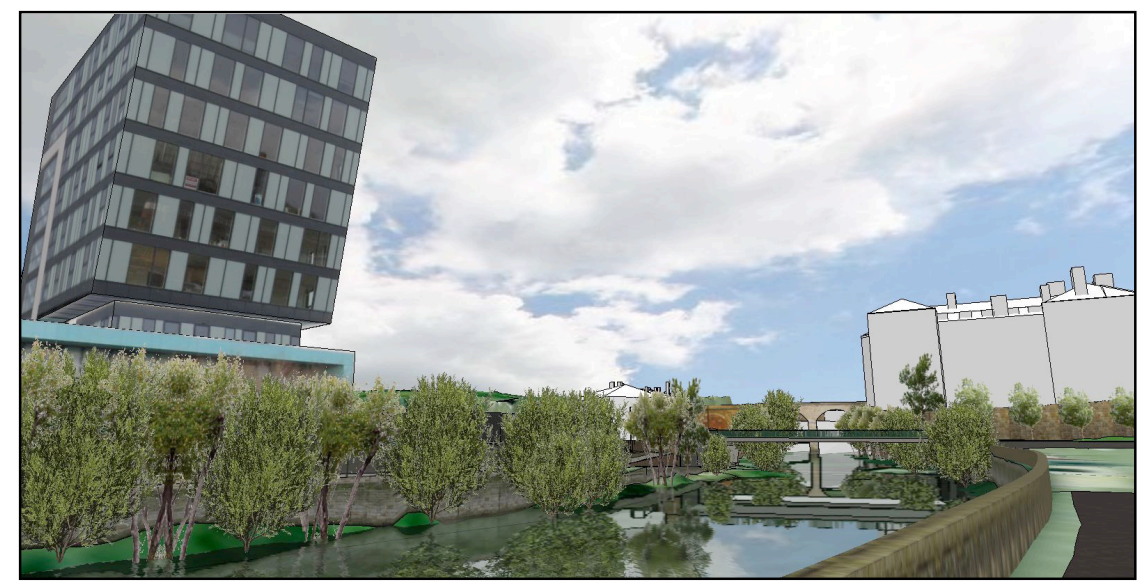

Figure 3. Blonk Street (VALUE)

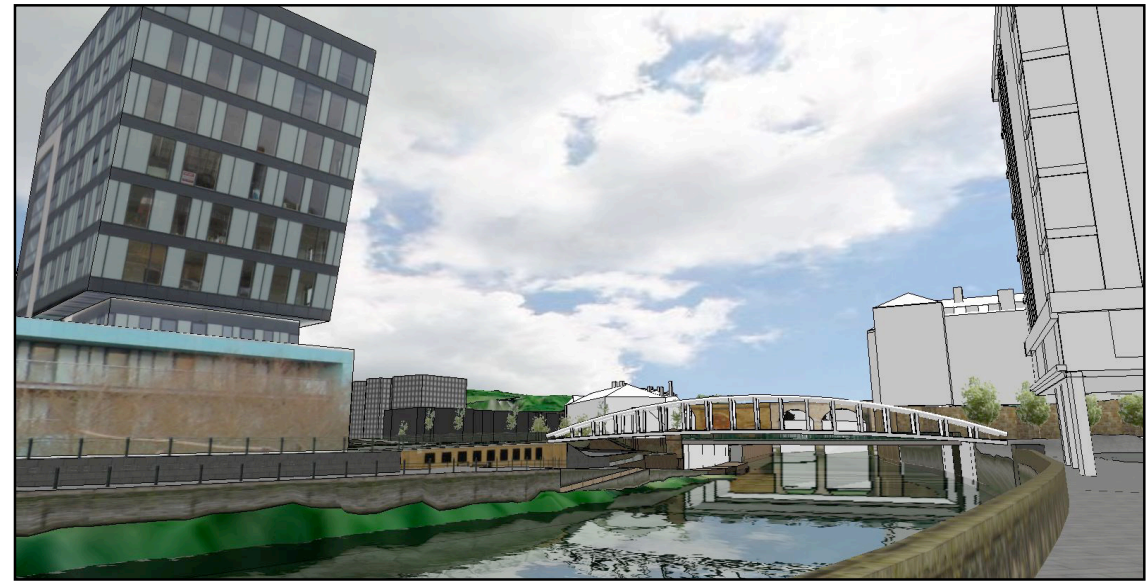


Figure 4. Blonk Street (scenario Sheffield City Council)

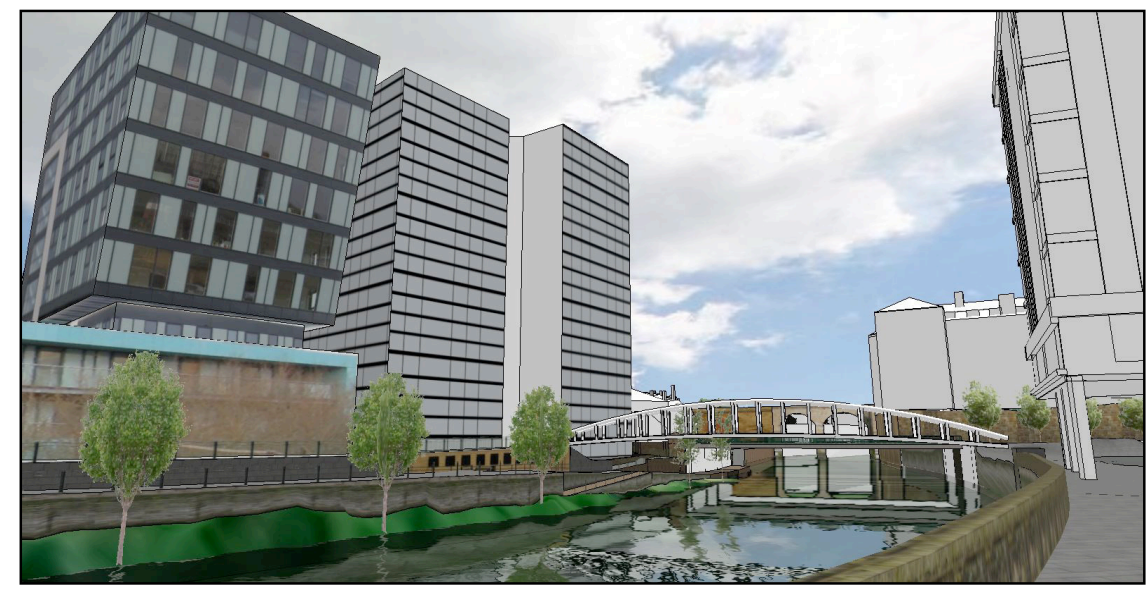

\section{Figure 5. Assessment of local green space}

SHOWCARD D (R) I'm going to read out a number of statements about the green spaces near your home. For each please tell me how much you agree or disagree with the statement. READ OUT a) to e). ROTATE ORDER - TICK START. SINGLE CODE ONLY FOR EACH QUESTION.

\begin{tabular}{|c|c|c|c|c|c|c|}
\hline & & $\begin{array}{l}\text { Strongly } \\
\text { agree }\end{array}$ & $\begin{array}{l}\text { Tend to } \\
\text { agree }\end{array}$ & $\begin{array}{l}\text { Neither } \\
\text { agree nor } \\
\text { disagree }\end{array}$ & $\begin{array}{l}\text { Tend to } \\
\text { disagree }\end{array}$ & $\begin{array}{l}\text { Strongly } \\
\text { disagree }\end{array}$ \\
\hline a) & $\begin{array}{l}\text { The green spaces in my local area are } \\
\text { maintained to a high standard }\end{array}$ & 1 & 2 & 3 & 4 & 5 \\
\hline b) & $\begin{array}{l}\text { The green spaces in my local area are of a } \\
\text { high quality }\end{array}$ & 1 & 2 & 3 & 4 & 5 \\
\hline c) & $\begin{array}{l}\text { The green spaces in my local area are } \\
\text { useful for local people }\end{array}$ & 1 & 2 & 3 & 4 & 5 \\
\hline d) & $\begin{array}{l}\text { The green spaces in my local area make a } \\
\text { difference in tackling climate change }\end{array}$ & 1 & 2 & 3 & 4 & 5 \\
\hline e) & $\begin{array}{l}\text { The green spaces in my local area provide } \\
\text { high quality biodiversity and habitat for } \\
\text { wildlife }\end{array}$ & 1 & 2 & 3 & 4 & 5 \\
\hline
\end{tabular}

\section{Willingness to Pay}

At the time of surveying the VALUE investment under investigation was constructed but was not yet fully accessible to the public. Consequently, to mitigate the potential interference of respondent expectations, a hypothetical payment market was constructed (Bateman et al., 2002). This situated the actual investment (Fig. 3) alongside two alternative scenarios (Fig. 2 and 4) to illustrate a range of potential development options for Blonk Street. Fig. 2 shows the situation prior to the investment, Fig 4 is an alternative planning proposal created by SCC. Each of the images developed illustrated significantly different levels of urban greening 
to allow respondents to make clear judgements about how much greenery was visible and what functionality these resources may have. Due to the complexity of conducting WTP surveys in parallel with the subject investment, the use of a realistic payment market was considered problematic. The WTP survey presented future-orientated payment options rather than payments for the ex-ante development situation.

\section{Fig 6. WTP question for Blonk Street investments}



The WTP question (see Fig. 6) asked participants to assume the role of a resident of The Wicker with a view of the GI investments portrayed in each visualisation. Posing an openended WTP question enabled the survey to address the differences between hypothetical and realistic markets (Bateman et al., 2002). The WTP question asked about regular monthly payments, rather than a one-off payment. This offers a more valid indication of WTP, because it establishes the longevity of the relationship between the respondents and the 
investment under investigation (Atkinson et al., 2008). A one-off payment by contrast equates to a capitalised repeat payment. However, research has shown that people are less able to assess the long-term value of a project when asked to indicate their WTP as a one-off charge (Mell et al., 2012a:14).

Participants were provided with a baseline typical monthly rental/mortgage interest payment for property in the area of $£ 575$ for a two-bedroom apartment (Mell et al., 2012a). The local housing stock is quite varied including terraced and semi-detached houses, as well as a range of apartments (mainly one- and two-bed units). The latter are the most numerous, hence the choice of base property. Respondents were asked how much more rent or mortgage (if any) they would be WTP per month to live in a flat overlooking each of the proposed investments.

An increase in rent/mortgage payment was considered the most appropriate form of payment for assessing respondents' perceptions of direct and indirect values because:

1. It is a payment most respondents are familiar with and pay;

2. It is a cost that people can interpret against their perceptions of local service provision and amenities;

3. It elicits responses, both positive and negative, as people are likely to have an opinion on rental/mortgage costs; and

4. It reflects the potential added value of green investment in the regeneration being undertaken in The Wicker Riverside.

The articulation of the WTP question was an important component of its effectiveness. Incremental payment increases were not used, as they were considered inappropriate for the development scenarios under investigation. An open-ended WTP question was used as it enabled people to apply a more interpretative evaluation to each investment.

\section{$3 D$ Visualisations of Blonk Street}

Supporting the WTP questions was a set of 3D visualisations. Virtual landscape models offer several advantages to WTP studies, including the ability to build scenarios of future investment strategies for existing landscapes (Mell et al., 2012a). Simmetry3d, a real-time visualisation software package was used to build the interactive landscape visualisations 
(Morgan et al., 2009). It has the capacity to import GIS, image data and data from other software (i.e. SketchUp and LENNÉ3D), whilst Vector GIS data was used to build models in SketchUp. Models were also constructed from photographs using the SktechUp 'PhotoMatch' feature (Morgan et al, 2009). A set of three investment scenarios was developed for the WTP survey illustrating the proposed treatments for Blonk Street (HehlLange et al., 2012). These were:

a) The 'before' investment scenario (Fig. 2): showing a vegetated river corridor, little public access to the riverfront, and existing bridge/river crossing.

b) The proposed 'VALUE' investment option (Fig. 3): showing a clear un-vegetated river channel, improved pedestrian access to the riverfront, new public walkways, and a redeveloped pedestrian bridge.

c) A greener option extending the level of greening outlined in the VALUE investment - 'scenario Sheffield City Council' (Fig. 4): showing new river corridor vegetation using new mature trees, associated on-site and street greening improved pedestrian access, and a redeveloped pedestrian footbridge.

\section{Survey administration}

510 questionnaires were completed in The Wicker over a six-week period (April-May 2013) covering 49 data collection sessions. Four shifts were used to conduct interviews solely with local businesses. In the remaining 45 sessions interviews were conducted with people using The Wicker and did not target any specific user groups (Fig. 7). The questionnaires were administered on-site (Mell et al., 2012a). A total of 1939 people were approached to achieve the 510 responses, a response rate of $26 \%$. The valuation questions were asked at the same point in each survey with the 3D visualisations being presented in a pre-determined randomised order (see Fig. 8). 
Figure 7. Survey respondents per category

\begin{tabular}{|l|c|c|}
\hline Category & $\begin{array}{c}\text { Interviews } \\
\text { achieved }\end{array}$ & $\begin{array}{c}\text { \% of } \\
\text { sample }\end{array}$ \\
\hline Resident & 87 & 17 \\
\hline Employee & 92 & 18 \\
\hline Business owner/senior manager & 25 & 5 \\
\hline Commuter & 61 & 12 \\
\hline Passing through & 46 & 9 \\
\hline Visiting family/friends & 36 & 7 \\
\hline Customer of shop/restaurant/ other business & 132 & 26 \\
\hline Some other reason & 31 & 6 \\
\hline Total & $\mathbf{5 1 0}$ & $\mathbf{1 0 0}$ \\
\hline
\end{tabular}

Figure 8. Scenario randomisation order

\begin{tabular}{|llcc|}
\hline & \multicolumn{3}{c|}{ Order of presentation } \\
& $\mathbf{1}^{\text {st }}$ & $\mathbf{2}^{\text {nd }}$ & $\mathbf{3}^{\text {rd }}$ \\
Blonk Street (Before) & 16 & 16 & 16 \\
Blonk Street (VALUE) & 16 & 16 & 16 \\
Blonk Street (scenario & 16 & 16 & 16 \\
Sheffield City Council) & \multicolumn{4}{|c}{} \\
\hline
\end{tabular}

\section{Analysis and Results}

The following sections present an analysis of survey data assessing if an association can be identified between GI and WTP. This discusses whether or not participants' WTP are associated with an understanding of the provision of amenities and access to GI in The Wicker. Both qualitative and quantitative forms of analysis were performed on the survey responses to explore the relationships between the structure of the physical environment, the context of the development scenarios and various socio-economic variables.

\section{WTP and preferences}

Figure 9 shows WTP and preferences for each of the development options proposed for The Wicker. The scenarios that were visibly greener (or perceived as more aesthetically pleasing as supported by the broader responses in Fig. 11) elicited higher WTP values and preference rates than those displaying greater proportions of urban/built features. The 'Before' option the greenest - was preferred by $53 \%$ of respondents, the equivalent figures for 'scenario Sheffield City Council' and the VALUE options were $47 \%$ and $7 \%$ respectively. The WTP highlighted a comparable pattern between the scenarios. Respondents were WTP an additional $£ 4.28$ per month for an apartment with a view of the 'VALUE' option, $£ 8.00$ more 
for a view of the 'scenario Sheffield City Council' and $£ 10.56$ more for a view of the 'Before' option. The greener the option, the more additional rent/mortgage payment respondents were willing to pay to overlook it. This supports the presumption in the research literature that greener and more accessible investments in GI generate greater WTP (Willis \& Garrod, 1992).

\section{Figure 9. Green investment preferences and WTP for Blonk Street}

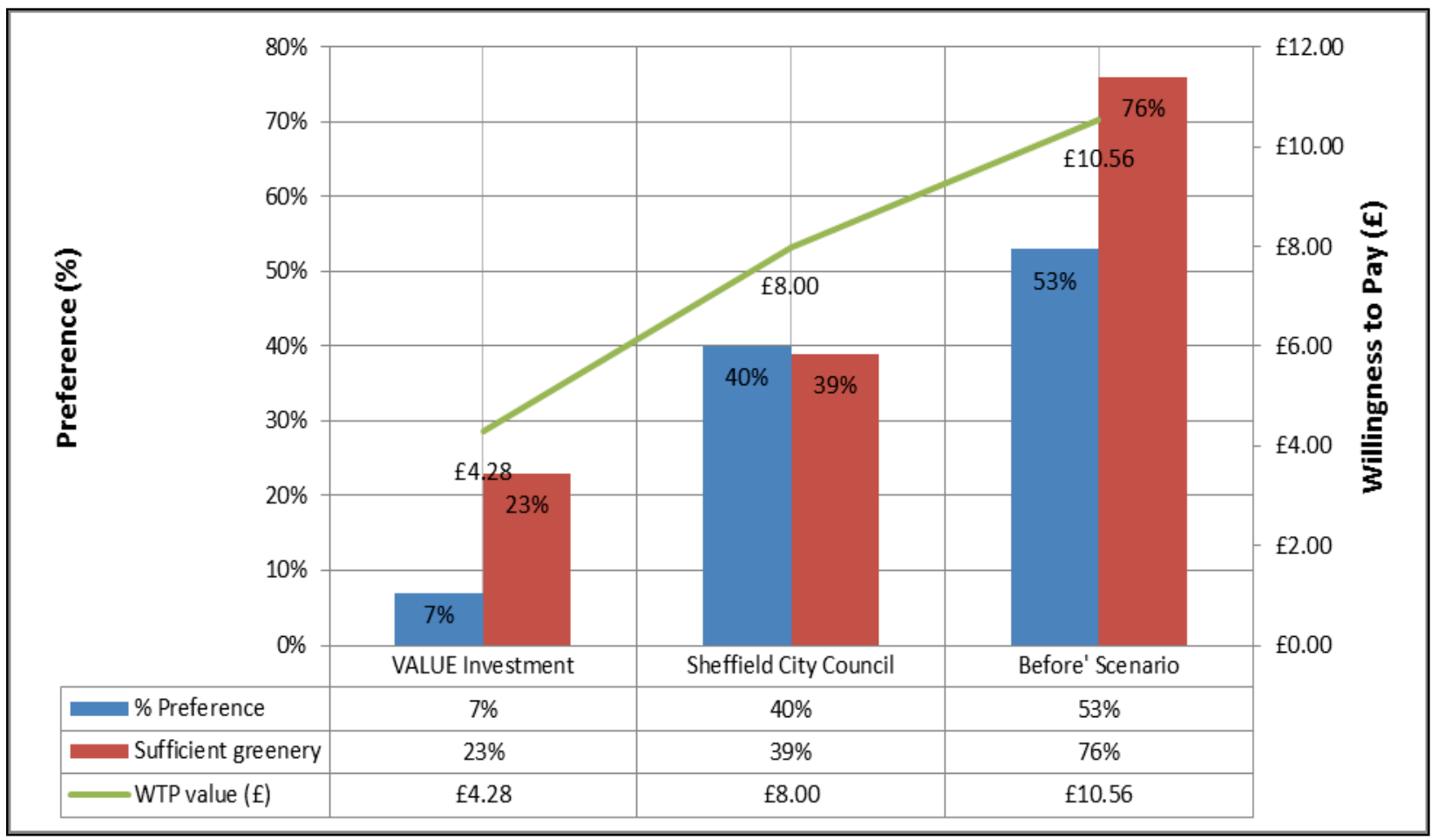

The relationship between respondents' WTP and their understanding of the value of urban greening was also examined. Respondents were asked to evaluate the contribution that GI might make to the quality of local life. Positive views of green infrastructure substantially outweighed negative ones for all facets of its general impact (see Figure 10). Figure 10 illustrates respondents' positive views of the contribution that GI might make to biodiversity/conservation, area maintenance and the accessibility to amenities generated by the increased multi-functionality of the landscape. For each aspect only a small percentage of negative comments (6-16\%) were recorded. This suggests that respondents consider Sheffield's landscape to be attractive, functional and well maintained, and that it makes a significant contribution to their quality of life. Preferences and WTP for GI investments are consistent with respondents' interpretations of the local and the wider urban realm. 
Figure 10. Green Investment contribution to local area

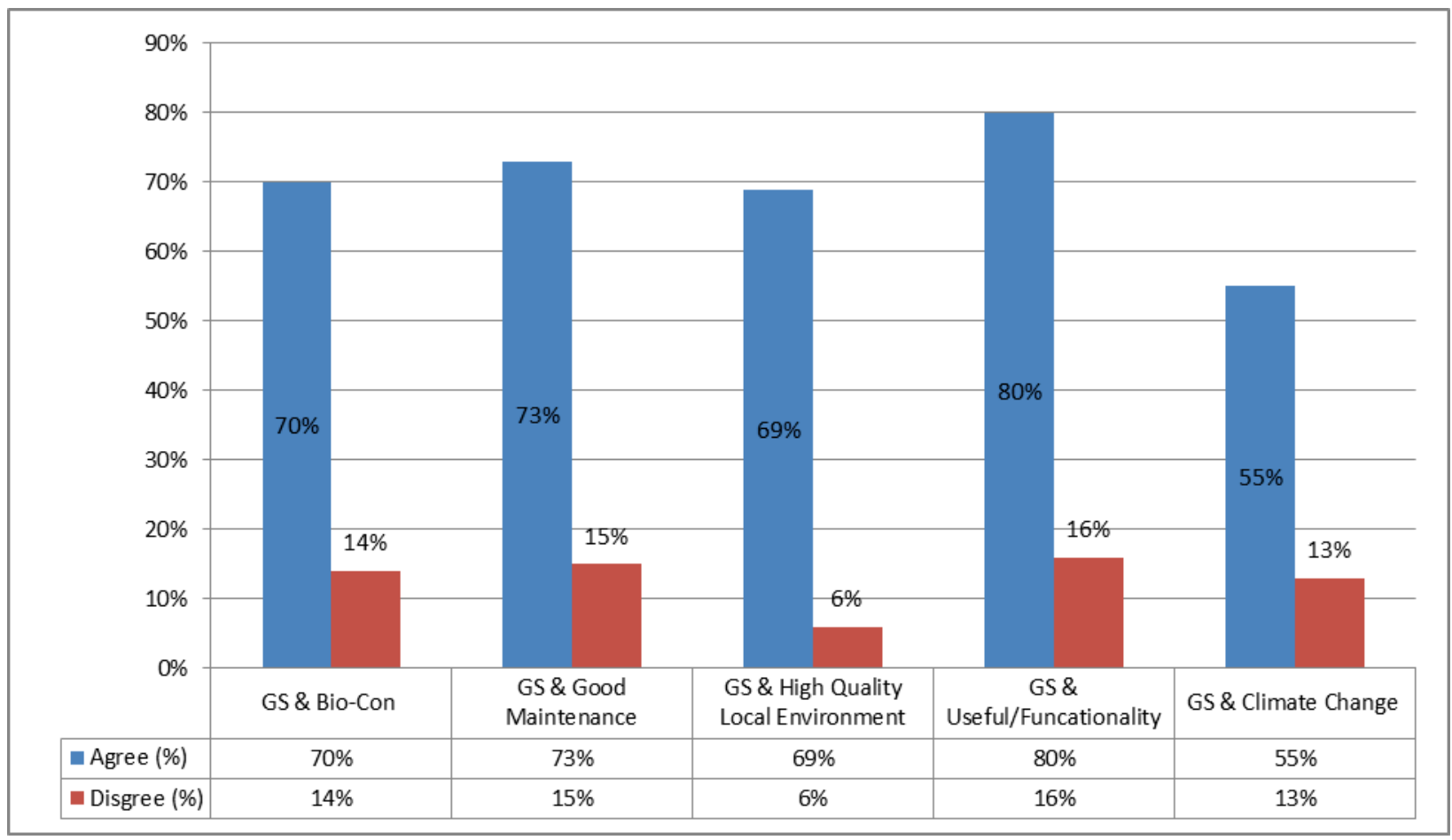

Respondents were also asked to distinguish the main reasons for their WTP for investments in green infrastructure (see Fig. 11 and 12). A range of responses was received that included both positive and negative interpretations of urban greening. Reviewing the visual characteristics, participants identified three main factors influencing WTP. Areas that look more natural (45\%), attractive (65\%) and more open (26\%) support more positive responses from participants (Fig. 11). In contrast, where respondents were unwilling to pay more for greening their reasons related mainly to economic issues (Fig. 12). People stated that current rent/mortgage costs were too high (41\%), that they could not afford to pay more $(21 \%)$ and that they did not want to pay for investments in GI (15\%). In contrast, over $40 \%$ of respondents stated that the personal cost of supporting GI was the main factor that reduced WTP. A lack of additional personal finances to support green investments was also frequently noted as further reason for limited WTP (Fig. 11). Furthermore, analysis of the aesthetic quality, accessibility and functionality of the set of images suggests that the visualisations were deemed useful in identifying whether the scenarios presented attractive $(69 \%$ positive responses), increasingly walkable areas (73\% positive responses), or would promote the use of GI ( $76 \%$ positive responses). The 'VALUE' option was not considered to be as 
aesthetically pleasing or functional with only $23 \%$ of respondents saying they would use this investment, whilst $76 \%$ of respondents showed a preference for the 'Before' scenario.

\section{Figure 11. Positive influences on WTP}

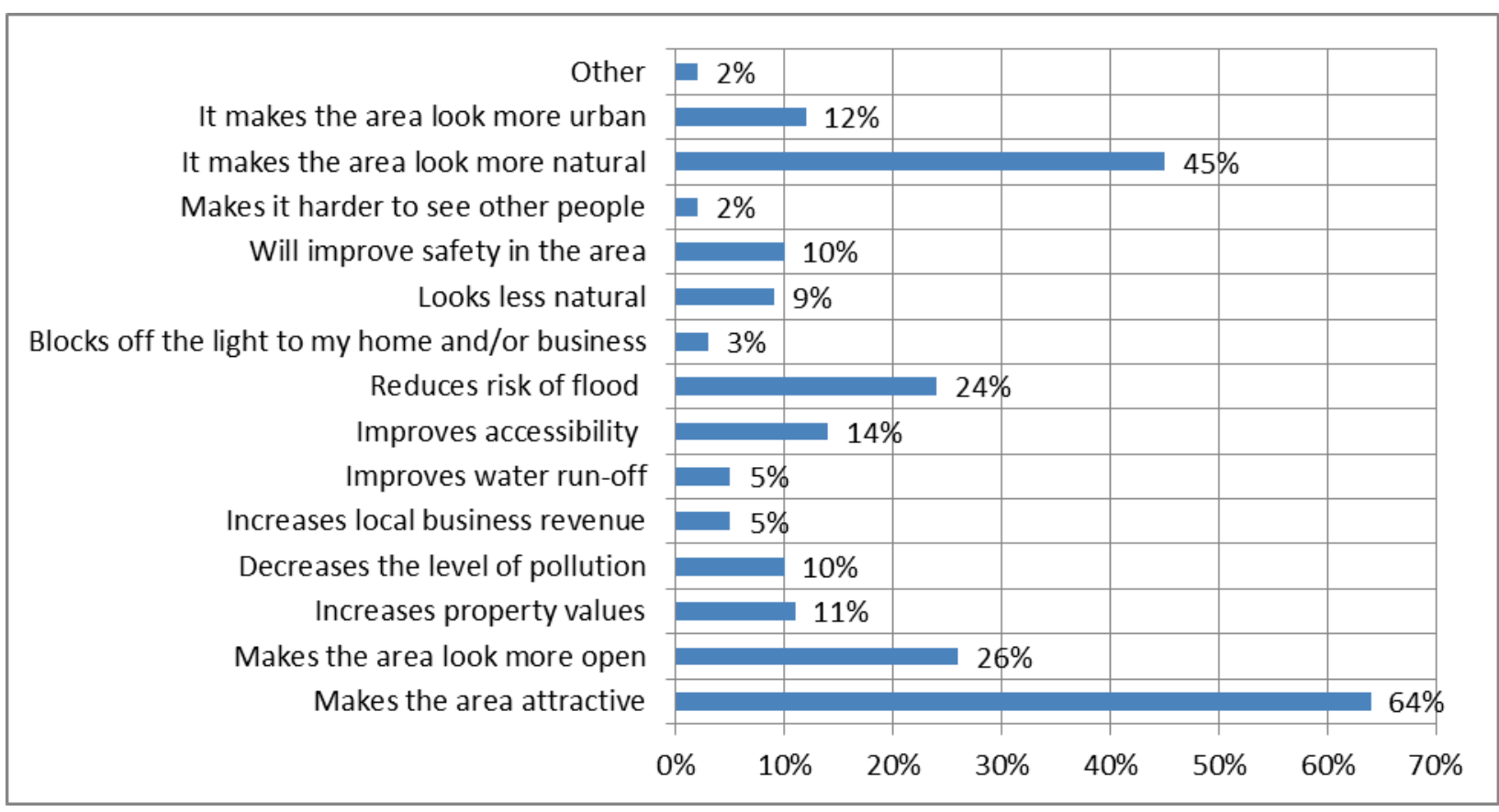

Figure 12. Negative influences on WTP

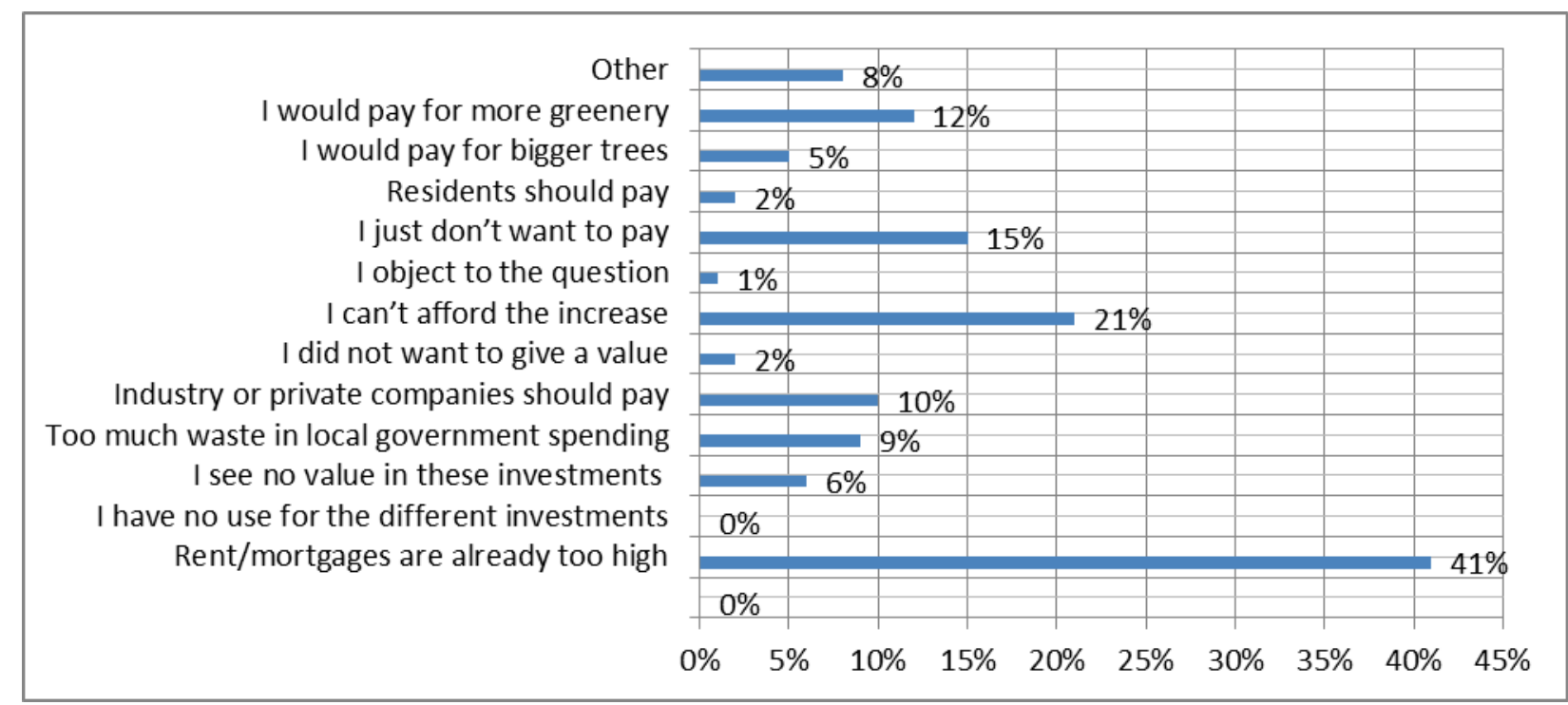

\section{Socio-economic variables}

Quantitative analysis was undertaken to examine the relationship between socio-economic variables (such as age, gender and employment status of respondents) and the WTP for GI 
using the chi-squared $\left(\mathrm{x}^{2}\right)$ test. Those variables displaying a statistically significant association with WTP are identified in Figure 13. There were strong relationships (indicated by $p$ values of $<0.05$ ) between WTP and eight socio-economic variables; with age and education displaying the most significant association with the development scenarios.

Figure 13. Chi-Squared $\left(\mathrm{X}^{2}\right)$ statistically significant relationship (WTP and socioeconomic characteristics)

\begin{tabular}{|c|c|c|c|c|c|c|c|c|}
\hline & 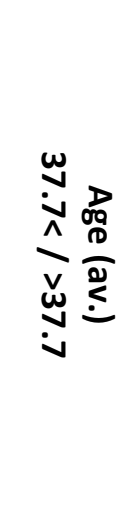 & 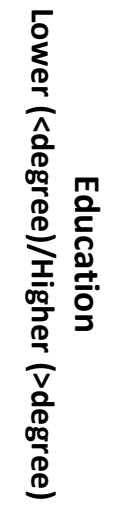 & 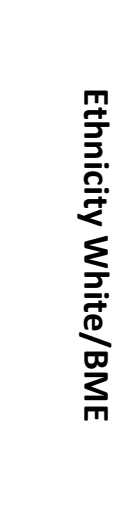 & 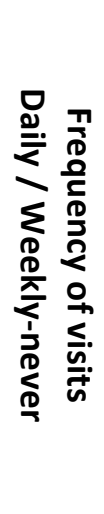 & 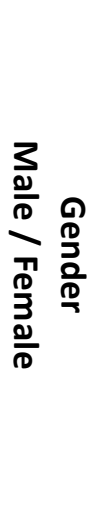 & 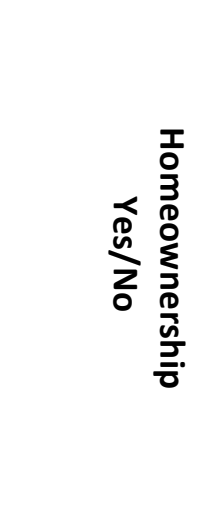 & 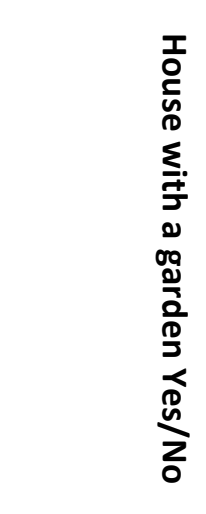 & 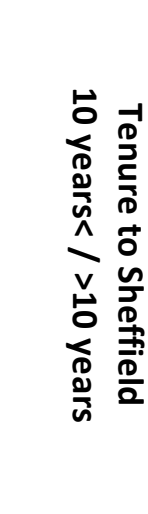 \\
\hline 'Before' & $\begin{array}{c}\checkmark \\
<37.7\end{array}$ & $\begin{array}{c}\checkmark \\
\text { Lower }\end{array}$ & $\begin{array}{c}\checkmark \\
\text { BME }\end{array}$ & & & $\begin{array}{c}\checkmark \\
\text { Homeowner }\end{array}$ & $\begin{array}{c}\checkmark \\
\text { No garden }\end{array}$ & $\begin{array}{c}\checkmark \\
>10 \text { years }\end{array}$ \\
\hline$x^{2}$ value & 5.447 & 10.892 & 14.087 & & & 4.282 & 3.894 & 4.275 \\
\hline$P$ value & 0.02 & 0.001 & 0.000 & & & 0.039 & 0.048 & 0.039 \\
\hline 'VALUE' & $\begin{array}{c}\checkmark \\
<37.7\end{array}$ & $\begin{array}{c}\checkmark \\
\text { Higher }\end{array}$ & & & & $\begin{array}{c}\checkmark \\
\text { Homeowner }\end{array}$ & $\begin{array}{c}\checkmark \\
\text { With garden }\end{array}$ & \\
\hline$x^{2}$ value & 3.894 & 9.632 & & & & 6.928 & 4.156 & \\
\hline$P$ value & 0.048 & 0.002 & & & & 0.008 & 0.041 & \\
\hline $\begin{array}{l}\text { 'Sheffield City } \\
\text { Council (SCC)' }\end{array}$ & $\begin{array}{c}\checkmark \\
<37.7\end{array}$ & $\begin{array}{c}\checkmark \\
\text { Lower }\end{array}$ & $\begin{array}{c}\checkmark \\
\text { BME }\end{array}$ & $\begin{array}{c}\checkmark \\
\text { Daily }\end{array}$ & $\begin{array}{c}\checkmark \\
\text { Male }\end{array}$ & $\begin{array}{c}\checkmark \\
\text { Homeowner }\end{array}$ & & \\
\hline$x^{2}$ value & 20.535 & 7.490 & 15.604 & 5.551 & 8.199 & 7.534 & & \\
\hline$P$ value & 0.000 & 0.006 & 0.000 & 0.018 & 0.04 & 0.006 & & \\
\hline
\end{tabular}

The chi-squared $\left(\mathrm{x}^{2}\right)$ analysis suggests that younger respondents (those aged $<27.7$ years) are WTP more for each development scenario than older respondents; and that lower educated respondents were WTP more for investments which showed more GI ('Before' and 'Sheffield City Council') compared to those classified as holding higher educational qualifications, although this tendency varied between the three scenarios. The analysis also indicates that there is an association between WTP for GI and homeownership compared to other tenures. Four other characteristics were also associated with WTP. Those respondents who identified themselves as Black and/or Minority Ethnic (BME) were WTP more for each of the greener investment scenarios (p-value: 0.00); whilst male respondents ( $p$-value: 0.04-0.002) were 
WTP more for the Sheffield City Council scenario. However, there was variation in the significance of these associations between the different scenarios.

\section{Discussion}

The analysis of The Wicker survey suggests that several respondent characteristics display a statistical association with WTP for GI and attitudes to urban greening. How 'green' a location is defined as the landscaping features visible in each image including river channel vegetation, street trees, increased grass verges/river banks and other aesthetic greening (it was not defined by a percentage of the image), its accessibility to the public and its perceived functionality in the provision of amenities/services were all strongly associated with a WTP more, as were investments that deliver a greater proportion of GI. The value of urban greening projects therefore appears to be related to the way that people interpret the form, as well as the utility, of the physical environment (Tyrväinen \& Väänänen, 1998). Our results are consistent with those of others active in the field of GI valuation, including the sister paper focussing on GI investment in Manchester (Mell et al., 2013), which found that successful urban greening is the product of an evolving interaction between engineered, but green, landscapes and the ability of people to engage in a range of activities in that space, that is affordances (UNEP-WCMC, 2011; Beatley, 2000).

Investments in GI can offer a more diverse range of options compared to overly engineered urban development by improving affordances (Thwaites et al., 2007; Louv, 2005). Gibson (1979) proposed that affordances are 'action possibilities' based on social interactions with the physical landscape. GI planning can thus be seen as an approach to place-making that, in light of the analysis of The Wicker survey, could be viewed as a socially and economically viable form of investment. Furthermore, the results of this survey compare favourably with Natural England's Monitor of Engagement with the Natural Environment Report (2013) because they highlight the validity of respondent statements linking functionality and aesthetic quality with the value of urban green space.

Although Pepper (1996) argued that nature has an innate worth that has become increasingly commodified, The Wicker analysis offers a more detailed understanding of the role urban greening plays in the functionality of cities. Whilst the analysis presented in this paper does not place intrinsic values on landscape resources, it does reveal a number of links between 
ecological, social and economic variables suggesting that valuation is a complex process. The shift in focus from the intrinsic worth of nature moving to the UNEP-WCMC's (2011) assumptions that an economic or commoditised worth can be hypothesised as a progression in the changing approaches to the valuation process. Such a transition, although difficult, could be considered to be increasingly necessary, as discussing urban greening from a commodified or economic perspective enables planners to engage more directly with the fiscal arguments presented by developers and other built environment professionals (Mell, 2016; Schäffler \& Swilling, 2012). Value and/or economic worth is thus a rational narrative within development conversations, where cost-benefit analysis and economic returns are often the primary objectives of investment. Although this may run counter to the more experiential understandings of landscape value proposed by Nassauer (1995) it can be a useful mechanism to facilitate a more engaged discourse for GI investment.

The results of the VALUE survey also indicate that - as GI becomes increasingly commoditised - it is possible to establish an economic rationale for such investment in a comparable way to other infrastructure investments. It is therefore becoming common practice for LAs and consultants to establish an economic case for GI prior to investment. The use of a variety of visual and textual mediums can thus be proposed as an effective means of facilitating the development of such economic analyse. Although there have been persistent warnings that commoditising GI may undermine the innate value of the landscape (Liu et al., 2010; Pepper, 1996), it has been argued as a necessary step if the tangible/intangible benefits of urban greening are to be understood by LAs, and more specifically developers. This reflects the increasing importance of explicit economic valuations in the GI development process, where financial returns are considered to be as important, if not more so, than their impact on landscape improvements on liveability. Such a process may run contrary to the discussions of the intangible nature of GI proposed by some advocates (cf. Mell, 2013), but should be seen as one that needs to be engaged with if investment in urban greening is to occur.

Advocates of GI planning propose that it offers an enabling framework for investment which integrates a conscious understanding of intrinsic worth with delivery (Benedict \& McMahon, 2006; Beatley, 2000). The result of this is a growing call for the inclusion of landscape valuations in development discussions that locate GI within the same debates as those 
relating to other built infrastructure. This should enable LAs and developers to optimise the viability of the physical environment to support social and economic needs through GI investments. To ensure equity in such a process the identification of specific economic values must run parallel to existing knowledge of socio-environmental interpretations of landscape worth (South Yorkshire Forest Partnership \& Sheffield City Council, 2012; Vandermeulen et al., 2011)

Analysis for The Wicker supports the findings of the previous VALUE investigation undertaken in Manchester, which found that people are WTP more for larger, greener and more functional green investments (Mell et al., 2013; South Yorkshire Forest Partnership \& Sheffield City Council, 2012). The results of the surveys in both Sheffield and Manchester suggest that it is possible to compare investment in urban GI in different locations. This raises the question posed by the VALUE project: is it possible to create a trans-national approach to economic evaluations for GI? A review of the published research undertaken for the VALUE project in Belgium and Germany, as well as in the UK, suggests that, although the development context varies, a trans-national approach to the methodological structure can be applied, achieving comparable results (Wilker \& Rusche, 2013; Vandermeulen et al., 2011). The analysis of both Manchester and Sheffield support a call for a more in-depth engagement with GI to generate a delivery framework enabling LAs to plan actively for investments in urban greening. At a UK level, planning policy and associated guidance is showing a greater understanding of the value of urban greening in respect of its economic worth and its role as a facilitator of improved quality of life (UNEP-WCMC, 2011). Such policy determinations, along with research from national agencies (e.g. Natural England, 2013), highlight the possibilities of improving economic returns through thoughtful, appropriate and functional investments in urban greenspaces.

The results of the Sheffield survey also provide a robust evidence base for SCC to integrate GI in future development policies. By focussing on how they integrate GI into urban development, SCC can mobilise investment, facilitating smarter, more sustainable and inclusive engagement with the urban environment (UNEP-WCMC, 2011). By promoting an increasingly green urban realm, SCC and other LAs can use the evidence presented in this paper, and by the wider VALUE project, to build business cases for GI development. Furthermore, through a process of extrapolation it is also possible to estimate the potential 
added value of green investments for The Wicker. Figure 14 suggests that, depending on the method of extrapolation, in this scenario Gross Impact on property values on Blonk Street, the additional returns in rent/mortgage payments following investment in GI could range from $£ 99,510.00$ for the 'VALUE' investment to $£ 186,000.00$ for SCC and $£ 251,322.50$ for the 'Before' scenario on Blonk Street (see Mell et al., 2012a: 58-60 for a more detailed discussion of the site's extrapolation) ${ }^{4}$. However, although extrapolations can be made based on the WTP values presented in this survey, a number of uncertainties need to be addressed. Firstly, extrapolation is based on the premise that the sample population is representative of the wider population of the area and the city of Sheffield. Secondly, the WTP values should be considered indicative of what people are prepared to pay for a specific investment project (Blonk Street) and investments in the wider area. Translating these results into practice may prove more difficult.

Figure 14: Estimate of Gross Impact of Blonk Street Options on Property Values

\begin{tabular}{|l|c|c|c|c|c|}
\hline $\begin{array}{c}\text { Investment } \\
\text { Option }\end{array}$ & $\begin{array}{c}\text { Average } \\
\text { rent } \\
\text { per unit } \\
(\mathbf{f} / \text { month) }\end{array}$ & $\begin{array}{c}\text { Average } \\
\text { WTP } \\
\text { per unit } \\
(\mathbf{f} / \text { month) }\end{array}$ & $\begin{array}{c}\text { Annual } \\
\text { rent } \\
\text { increase } \\
\text { per unit } \\
(\mathbf{f} \text { pa) }\end{array}$ & $\begin{array}{c}\text { Annual } \\
\text { rent } \\
\text { increase } \\
\text { per unit } \\
\text { (f pa) }\end{array}$ & $\begin{array}{c}\text { Gross extra } \\
\text { capital value } \\
\text { at yield of }^{2} \\
\mathbf{8 . 0 0 \%} \\
(\mathbf{f})\end{array}$ \\
\hline Before & $£ 575.00$ & $£ 10.81$ & $£ 129.72$ & $£ 20,106.60$ & $£ 251,332.50$ \\
\hline VALUE & $£ 575.00$ & $£ 4.28$ & $£ 51.36$ & $£ 7,960.80$ & $£ 99,510.00$ \\
\hline SCC Scenario & $£ 575.00$ & $£ 8.00$ & $£ 96.00$ & $£ 14,880.00$ & $£ 186,000.00$ \\
\hline
\end{tabular}

1. Number of dwellings with view of Blonk Street investments.

2. Median PRS yield in Northern cities (Source: Knight Frank, 2014).

The potential economic value of investments, such as those in The Wicker, is in the ability of GI to offer a range of investment options providing scope for planners to think innovatively about the relationships people have with urban landscapes. The analysis presented in this paper thus supports the research of Thwaites et al. (2007) and Louv (2005) who state that landscapes which are attractive offer opportunities to engage with a variety of amenities and services, making places more liveable. If we consider valuation as a circular process of appraisal and re-interpretation of ecological, social and economic variables it can enable planners to integrate public reactions to urban space into future plans.

\footnotetext{
${ }^{4}$ The extrapolation model utilised in these calculations corresponds to that used by Knight Frank (2014) and is based on a median PRS (Private Rental Sector) yield in northern UK cities.
} 


\section{Conclusion}

The results of The Wicker investigation illustrate that there is a WTP more for urban environments that are perceived to be greener and offer increased functionality. The level of financial commitment allocated through additional rental/mortgage payments is derived from an assessment of the physical, social and economic value an individual, and in some cases communities, place on specific forms of urban greening. WTP more and stronger preferences were associated with increases in the proportion of greenery shown in the investment options. While 'visible' greenness is an important influence on WTP, the perceived value of physical infrastructure also needs to be considered. The nature, size and function of different GI investments therefore need to be assessed to ensure the maximum economic value (and returns) are attributed to an investment. Positive assessments of green investment are also related to interpretations of a location's management. This suggests that a relationship exists between the visual attractiveness of a development option, its accessibility, its permeability as a public space and the level of greenery. Where an option is perceived to be aesthetically of a high quality a corresponding interpretation of high accessibility was noted. Furthermore, where participant responses to perceived attractiveness, accessibility to amenities and visible greenery were deemed positive there is a statistical association with increased WTP for GI. Investment in GI can therefore be seen as being one investment option that can increase the economically viability of an urban development project, especially where it helps to address local needs or deficiencies in green and open space.

\section{Acknowledgements}

This paper is based on work undertaken for an international, collaborative research programme on 'Valuing Attractive Landscapes in the Urban Economy' (VALUE) funded by the European Regional Development Fund (ERDF) under its INTERREG IVB, North-West Europe, Community Initiative concerning Promoting Strong and Prosperous Communities at Transnational Level 2007-2013. The authors would like to thank the contributions of the URSULA project in developing the visualisations and making these available for the VALUE project. Special thanks go to Eckart Lange, Ed Morgan and Lewis Gill for their assistance in this process. 


\section{Bibliography}

Anyika, B. (2011). Work Package 4, Action 4.1: Report on Focus Group Interviews in Sheffield. VALUE Investment Site: Sheffield North Ban Business Disrict Greenway Programme. Sheffield.

Atkinson, G., Mourato, S., Szymanski, S. \& Ozdemiroglu, E. (2008). Are We Willing to Pay Enough to 'Back the Bid'?: Valuing the Intangible Impacts of London's Bid to Host the 2012 Summer Olympic Games. Urban Studies, 45(2), 419-444.

Bateman, I. J., Carson, R. T., Day, B., Hanemann, M., Hanley, N., Hett, T., et al. (2002). Economic Valuation with Stated Preference Techniques: A Manual. London: Edward Elgar Publishing Ltd.

Beatley, T. (2000). Green Urbanism: Learning from European Cities. Washington DC: Island Press.

Benedict, M. A. \& McMahon, E. T. (2006). Green Infrastructure: Linking Landscapes and Communities. Washington DC: Island Press.

CABE Space. (2004). Green Space Strategies: A Good Practice Guide. London.

CABE Space. (2005). Does Money Grow on Trees? London.

Campbell, S. (1996). Green Cities, Growing Cities, Just Cities?: Urban Planning and the Contradictions of Sustainable Development. Journal of the American Planning Association, 62(3), 296-312.

Chatterton, J., Viavattene, C., Morris, J., Penning-Roswell, E. \& Tapsell, S. (2010). The Costs of the Summer 2007 Floods in England. Flood and Coastal Erosion Risk Management Research and Development Programme Project: SC070039/R1. Bristol.

Crompton, J. L. (2001). The Effects of Different Types of Information Messages on Perceptions of Price and Stated Willingness-to-Pay. Journal of Leisure Research, 33(3), $299-318$.

Daily, G., Polasky, S., Goldstein, J., Kareiva, P., Mooney, H., Pejchar, L., et al. (2009). Ecosystem Services in Decision Making: Time to Deliver. Frontiers in Ecology and the Environment, 7, 21-28.

Environment Agency. (2007). Review of 2007 Summer Floods. Bristol.

Garrod, G., Pickering, A. \& Willis, K. (1993). The Economic Value of Botanic Gardens: A 
Recreational Perspective. Geoforum, 24(2), 215-224.

Gibson, J. (1979). The Ecological Approach to Visual Perception. Boston: Houghton Mifflin Company.

Gómez-Baggethun, E., de Groot, R., Lomas, P. \& Montes, C. (2010). The History of Ecosystem Services in Economic Theory and Practice: From Early Notions of Markets to Payment Schemes. Ecological Economics, 69(6), 1209-1218.

Hehl-Lange, S., Gill, S. L., Henneberry, J., Keskin, B., Lange, E., Mell, I. C., et al. (2012). Using 3D Virtual GeoDesigns for Exploring the Economic Value of Alternative Green Infrastructure Options, in: Buhmann, E., Irvin, S., and Pietsch, M. (Eds.), GeoDesign, 3D-Modelling and Visualization, (pp. 273-280). Heidelberg: Wichmann.

Jim, C. (2004). Green-Space Preservation and Allocation for Sustainable Greening of Compact Cities. Cities, 21(4), 311-320.

Jim, C. \& Chen, W. Y. (2006). Recreation-amenity Use and Contingent Valuation of Urban Greenspaces in Guangzhou, China. Landscape and Urban Planning, 75(1-2), 81-96.

Jones, S. \& Somper, C. (2014). The Role of Green Infrastructure in Climate Change Adaptation in London. The Geographical Journal, 180(2), 191-196.

Knight Frank. (2014). The Rental Revolution: Examining the Private Rented Sector 2014.

Retrieved September 2, 2015, from

http://content.knightfrank.com/research/587/documents/en/2014-1726.pdf

Lachmund, J. (2013). Greening Berlin: The Co-Production of Science, Politics, and Urban Nature. Cambridge: MIT Press.

Laing, R., Davies, A.-M. \& Scott, S. (2002). Combining Visualisation and Choice Experiments in Built Environment Research, in: Proceedings Sixth International Conference on Information Visualisation, (pp. 785-790). IEEE Comput. Soc. Landscape Institute. (2009). Green Infrastructure: Connected and Multifunctional Landscapes. Landscape Institute Position Statement. London.

Lange, E. (2001). The Limits of Realism: Perceptions of Virtual Landscapes. Landscape and Urban Planning, 1-4, 163-182.

Lennon, M. (2014). Presentation and Persuasion: The Meaning of Evidence in Irish Green Infrastructure Policy. Evidence \& Policy: A Journal of Research, Debate and Practice, 
10(2), 167-186.

Liu, S., Constanza, R., Troy, A., D’Aagostino, J. \& Mates, W. (2010). Valuing New Jersey’s Ecosystem Services and Natural Capital: A Spatially Explicit Benefit Transfer Approach. Environmental Management, 45(6), 1271-1285.

Louv, R. (2005). Last Child in the Woods: Saving Our Children from Nature-Deficit Disorder. Algonquin Books of Chapel Hill.

Mell, I. C. (2010). Green Infrastructure: Concepts, Perceptions and Its Use in Spatial Planning. Unpublished thesis, Univerewity of Newcastle.

Mell, I. C. (2013). Can You Tell a Green Field from a Cold Steel Rail ? Examining the ‘ Green ' of Green Infrastructure Development. Local Environment: The International Journal of Justice and Sustainability: The International Journal of Justice and Sustainability, 18(2), 37-41.

Mell, I. C. (2016). GI Management - Time to 'let Someone Else Have a Go'? Town and Country Planning, March/Apri, 138-141.

Mell, I. C., Henneberry, J., Hehl-Lange, S. \& Keskin, B. (2013). Promoting Urban Greening: Valuing the Development of Green Infrastructure Investments in the Urban Core of Manchester, UK. Urban Forestry \& Urban Greening, 12(3), 296-306.

Mell, I. C., Keskin, B., Hehl-Lange, S. \& Henneberry, J. (2012a). Action 4.2 Level II Report: A Contingent Valuation of Green Investments in The Wicker Riverside, Sheffield. Sheffield.

Mell, I. C., Keskin, B., Hehl-Lange, S. \& Henneberry, J. (2012b). Action 4.2 Case Study Report - Street Tree Investments on Whitworth Street West, Manchester. Sheffield.

Morgan, E., Gill, L., Lange, E. \& Romano, D. (2009). Rapid Prototyping of Urban River Corridors Using 3D Interactive, Real-Time Graphics., in: Proceedings Digital Landscape Architecture 2009, (pp. 198-205). Anhalt, Malta: Anhalt University of Applied Sciences.

Nassauer, J. (1995). Culture and Changing Landscape Structure. Landscape Ecology, 10(4), $229-237$.

Natural England. (2013). Monitor of Engagement with the Natural Environment: Key Findings from the Survey. Peterborough. 
Natural England \& Landuse Consultants. (2009). Green Infrastructure Guidance.

Peterborough.

Pepper, D. (1996). Modern Environmentalism: An Introduction. Routledge.

Schäffler, A. \& Swilling, M. (2012). Valuing Green Infrastructure in an Urban Environment Under Pressure - The Johannesburg Case. Ecological Economics, 86, 246-257.

Selman, P. (2009). Planning for Landscape Multifunctionality. Sustainability: Science, practice and policy, 5(2), 45-52.

Sheffiled City Council. (2009). Sheffield Development Framework - Core Strategy (Adopted March 2009). Sheffield.

South Yorkshire Forest Partnership \& Sheffield City Council. (2012). The VALUE Project: The Final Report. Sheffield.

Thwaites, K., Porta, S., Romice, O. \& Greaves, M. (2007). Urban Sustainability through Environmental Design: Approaches to Time-People-Place Responsive Urban Spaces (K. Thwaites, S. Porta, O. Romice, and M. Greaves, Eds.). Abingdon: Routledge.

Todorova, A., Asakawa, S. \& Aikoh, T. (2004). Preferences for and Attitudes towards Street Flowers and Trees in Sapporo, Japan. Landscape and Urban Planning, 69(4), 403-416.

Town \& Country Planning Association. (2004). Biodiversity By Design $\cdot$ Projects \& Publications. London.

Tyrväinen, L. (2001). Economic Valuation of Urban Forest Benefits in Finland. Journal of environmental management, 62(1), 75-92.

Tyrväinen, L. \& Väänänen, H. (1998). The Economic Value of Urban Forest Amenities: An Application of the Contingent Valuation Method. Landscape and Urban Planning, 43(13), 105-118.

UNEP-WCMC. (2011). UK National Ecosystem Assessment: Understanding Nature's Value to Society. Synthesis of Key Findings. Cambridge.

Vandermeulen, V., Verspecht, A., Vermeire, B., Van Huylenbroeck, G. \& Gellynck, X. (2011). The Use of Economic Valuation to Create Public Support for Green Infrastructure Investments in Urban Areas. Landscape and Urban Planning, 103(2), 198-206.

Walmsley, A. (2006). Greenways: Multiplying and Diversifying in the 21 st Century. 
Landscape and Urban Planning, 76(1-4), 252-290.

Wild, T., Hathway, E., Moore, S., Shaw, E., Moug, P. \& Lerner, D. (2008). The State of Sheffield's Urban River Corridors - URSULA Project Report 1. Sheffield.

Wilker, J. \& Rusche, K. (2013). Economic Valuation as a Tool to Support Decision-Making in Strategic Green Infrastructure Planning. Local Environment, 19(6), 702-713.

Wilker, J., Rusche, K. \& Rymsa-Fitschen, C. (2016). Improving Participation in Green Infrastructure Planning. Planning Practice \& Research, 1-21. Retrieved March 26, 2016, from http:/www.tandfonline.com/doi/abs/10.1080/02697459.2016.1158065

Willis, K. \& Garrod, G. (1992). Assessing the Value of Future Landscapes. Landscape and Urban Planning, 23(1), 17-32. 